ADALAH : Buletin Hukum \&

Keadilan

Buletin Hukum \& Keadilan

@adalahuinjkt

\title{
Demokrasi dan Keadilan Sebagai Legitimasi Suara Rakyat

\author{
Sujatmiko*
}

Manusia diciptakan oleh Tuhan Yang Maha Esa dengan seperangkat hak yang menjamin derajatnya sebagai manusia. Hak-hak inilah yang kemudian disebut dengan Hak Asasi Manusia, yaitu hak yang diperoleh sejak kelahirannya sebagai manusia yang merupakan karunia Sang Pencipta. Dalam kenyataannya, manusia selalu hidup dalam komunitas sosial untuk dapat menjaga derajat kemanusiaan dan mencapai tujuannya. Akibatnya, muncul struktur sosial. Sehingga dibutuhkan kekuasaan untuk menjalankan organisasi sosial tersebut. Kekuasaan dalam suatu organisasi dapat diperoleh berdasarkan legitimasi religius, legitimasi ideologis eliter dan legitimasi pragmatis. Hanya saja legitimasi-legitimasi tersebut, cenderung mengarah pada kekuasaan yang absolut, karena kewenangan yang dimiliki menjadikan ketiga legitimasi tersebut menjadi kekuasaan yang otoriter (Nugroho, 2013: 248).

Suatu pemerintahan secara rasional tidak mungkin lagi menyandarkan wewenang dan kekuasaannya atas dasar kekuatan fisik yang represif seperti militer,

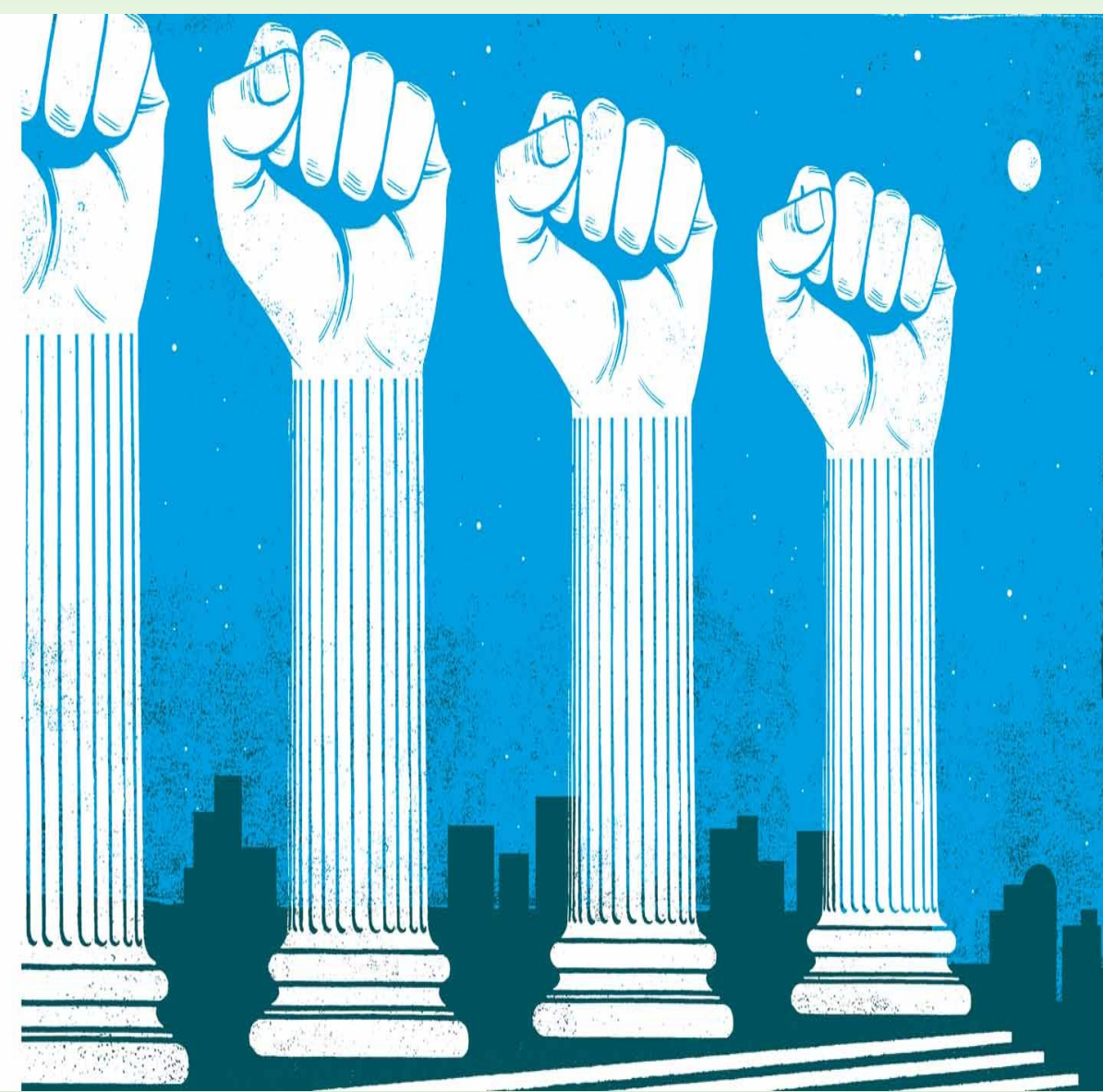

atau pun pada mitos-mitos feodalistik maupun teokratik. Halhal yang bersifat irrasional dan dipaksakan semakin lama semakin ditinggalkan sejalan dengan perkembangan pemikiran filsafat dan politik serta teknologi. Jadi, tanpa ada legitimasi yang rasional, maka suatu negara tidak mungkin akan berjalan secara efektif. Legitimasi atas suatu negara (Maggalatung, 2013: 96). 
Untuk mencapai pembenaran yang rasional dibutuhkan dua komponen yang merupakan suara sejati rakyat. Dua hal itu tidak lain adalah demokrasi dan keadilan. Keduanya merupakan dua kata yang berbeda tetapi tidak dapat dipisahkan, karena memiliki keterkaitan yang begitu ketatnya. Ketika demokrasi dan keadilan menjadi dambaan setiap orang, maka demokrasi dan keadilan harus sesuai dengan hati nurani rakyat. Sebab, rakyatlah pemilik "demokrasi" dan "keadilan" yang sesungguhnya.

Di Indonesia sendiri demokrasi dan keadilan sering menjadi objek yang dipermasalahkan. Masalah yang dihadapi Indonesia memang berat, tapi jika tidak ada ketegasan dari pemerintah malah akan membuat masalah yang ada akan semakin sulit dan kepercayaan masyarakat pada kinerja dan efektivitas pemerintahan akan semakin berkurang. Dengan begitu pada akhirnya pemerintahan tidak akan memiliki legitimasi. Padahal dalam "demokrasi" ada istilah suara rakyat adalah suara Tuhan, dan dalam "keadilan" tersimpan rasa kemanusiaan yang sangat mendalam yang disebut sebagai

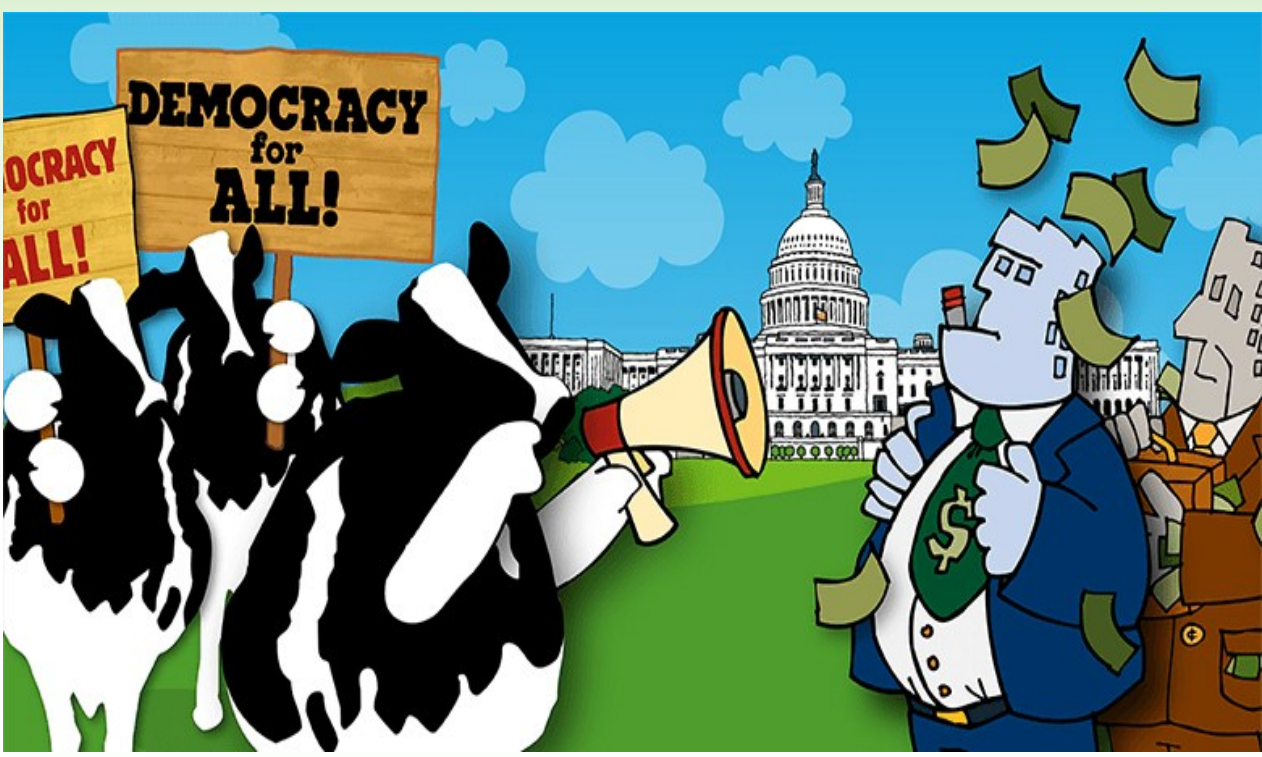
keadilan substantif. Keadilan yang sesuai dengan rasa kemanusiaan.

Apabila ketidakadilan dan ketidaktegasan seperti itu terjadi, pemerintah secara tidak langsung membuat rakyat bertindak sendiri dengan berdemonstrasi menuntut keadilan dan berbuat onar dan bisa saja bertindak kekerasan dan merusak fasilitas umum karena kekecewaannya terhadap pemerintahan yang dijalankan di Indonesia saat ini. Bila demokrasi dan keadilan semakin menggelinding jauh, maka kebenaran yang sejatilah yang akan muncul. Kebenaran yang sesuai dengan hati nurani rakyat. Ketika suara hati nurani rakyat itu muncul, maka didalam mencari kebenaran dan menegakkan keadilan substantif, tidak akan terbendung oleh siapapun.

Sungguh merupakan pembelajaran yang sangat berharga bagi kita semua. Betapa pentingnya mendengarkan suara rakyat. Politisi yang gagal mendengarkan suara rakyat, mungkin tidak akan terpilih lagi. Pemimpin yang tidak mendengarkan suara rakyat, juga akan ditinggalkan rakyat. Mungkin benar, sekali atau dua kali, kita bisa mengelabui rakyat. Yang pasti, tidak akan selamanya. Sebab, rakyat akan semakin pandai, dan semakin cerdik memahami nasibnya. "Kebenaran" dan "keadilan substantif" pasti akan menang. Inilah makna demokrasi, bahwa keberpihakan dan bersikap adil akan mewujudkan 